\title{
Lighten up the dark: metazoan parasites as indicators for the ecology of Antarctic crocodile icefish (Channichthyidae) from the north-west Antarctic Peninsula
}

\author{
Thomas Kuhn ${ }^{1}$, Vera M A Zizka ${ }^{2}$, Julian Münster ${ }^{\text {Corresp., }}{ }^{1}$, Regina Klapper ${ }^{1}$, Simonetta Mattiucci ${ }^{3}$, Judith \\ Kochmann ${ }^{1}$, Sven Klimpel ${ }^{1}$ \\ 1 Institute for Ecology, Evolution and Diversity, Johann Wolfgang Goethe Universityt, Senckenberg Biodiversity and Climate Research Centre, Senckenberg \\ Gesellschaft für Naturforschung, Frankfurt am Main, Germany \\ 2 Aquatic Ecosystem Research, Faculty of Biology, University of Duisburg-Essen, Essen, Germany \\ 3 Department of Public Health and Infectious Diseases, Section of Parasitology, University of Roma "La Sapienza", Rome, Italy \\ Corresponding Author: Julian Münster \\ Email address: muenster@em.uni-frankfurt.de
}

Due to its remote and isolated location, Antarctica is home to a unique diversity of species. The harsh conditions have shaped a primarily highly adapted endemic fauna. This includes the notothenioid family Channichthyidae. Their exceptional physiological adaptations have made this family of icefish the focus of many studies. However, studies on their ecology, especially on their parasite fauna, are comparatively rare. Parasites, directly linked to the food chain, can function as biological indicators and provide valuable information on host ecology (e.g. trophic interactions) even in remote habitats with limited accessibility, such as the Southern Ocean. In the present study, channichthyid fish (Champsocephalus gunnari: $n=25$, Chaenodraco wilsoni: $n=33$, Neopagetopsis ionah: $n=3$, Pagetopsis macropterus: $n=4$, Pseudochaenichthys georgianus: $n=15$ ) were collected off South Shetland Island, Elephant Island and the tip of the Antarctic Peninsula (CCAML statistical subarea 48.1). The parasite fauna consisted of 14 genera and 15 species, belonging to the six taxonomic groups including Digenea (4 species), Nematoda (4), Cestoda (2), Acanthocephala (1), Hirudinea (3), and Copepoda (1). The stomach contents were less diverse with only Crustacea (Euphausiacea, Amphipoda) recovered from all examined fishes. Overall, 15 new parasite-host records could be established, and possibly a new genotype or even species might exist among the nematodes. 
1 Lighten up the dark: metazoan parasites as indicators for the ecology of Antarctic crocodile

2 icefish (Channichthyidae) from the north-west Antarctic Peninsula

5 Thomas Kuhn, Vera MA Zizka ${ }^{\text {b }}$, Julian Münster ${ }^{\mathrm{a},}{ }^{*}$, Regina Klapper $^{\mathrm{a}}$, Simonetta Mattiuccic,

6 Judith Kochmann ${ }^{\text {a }}$, Sven Klimpel ${ }^{\mathrm{a}}$

7

8 a Goethe-University, Institute for Ecology, Evolution and Diversity; Senckenberg Biodiversity and

9 Climate Research Centre, Senckenberg Gesellschaft für Naturforschung; Max-von-Laue-Str. 13,

10 D-60438 Frankfurt/Main, Germany

12 b Aquatic Ecosystem Research, Faculty of Biology, University of Duisburg-Essen,

13 Universitätsstraße 5, 45141 Essen, Germany

b Department of Public Health and Infectious Diseases, Section of Parasitology, "Sapienza-

16 University of Rome”, p.1e Aldo Moro, 5, 00185, Italy

19 Corresponding author:

* Goethe-University, Institute for Ecology, Evolution and Diversity; Senckenberg Biodiversity

21 and Climate Research Centre, Senckenberg Gesellschaft für Naturforschung; Max-von-Laue-Str.

22 13, D-60438 Frankfurt/Main, Germany. Ph.: +49-69-798-42235, Fax: +49-69-798-42236

23 Email address: muenster@em.uni-frankfurt.de 


\section{ABSTRACT}

27 Due to its remote and isolated location, Antarctica is home to a unique diversity of species. The 28 harsh conditions have shaped a primarily highly adapted endemic fauna. This includes the 29 notothenioid family Channichthyidae. Their exceptional physiological adaptations have made this 30 family of icefish the focus of many studies. However, studies on their ecology, especially on their 31 parasite fauna, are comparatively rare. Parasites, directly linked to the food chain, can function as 32 biological indicators and provide valuable information on host ecology (e.g. trophic interactions) 33 even in remote habitats with limited accessibility, such as the Southern Ocean. In the present study, 34 channichthyid fish (Champsocephalus gunnari: $\mathrm{n}=25$, Chaenodraco wilsoni: $\mathrm{n}=33$, 35 Neopagetopsis ionah: $\mathrm{n}=3$, Pagetopsis macropterus: $\mathrm{n}=4$, Pseudochaenichthys georgianus: $\mathrm{n}=$ 36 15) were collected off South Shetland Island, Elephant Island and the tip of the Antarctic Peninsula 37 (CCAML statistical subarea 48.1). The parasite fauna consisted of 14 genera and 15 species, 38 belonging to the six taxonomic groups including Digenea (4 species), Nematoda (4), Cestoda (2), 39 Acanthocephala (1), Hirudinea (3), and Copepoda (1). The stomach contents were less diverse 40 with only Crustacea (Euphausiacea, Amphipoda) recovered from all examined fishes. Overall, 15 41 new parasite-host records could be established, and possibly a new genotype or even species might 42 exist among the nematodes.

45 Running head: Metazoan parasite fauna of Channichthyidae from waters off South Shetland 46 Islands and Elephant Island 
Keywords: Channichthyidae, anisakid nematodes, Contracaecum, Pseudoterranova,

49 Champsocephalus gunnari, Chaenodraco wilsoni, Neopagetopsis ionah, Pagetopsis

50 macropterus, Pseudochaenichthys georgianus

51

52

\section{Introduction}

The exploration of remote habitats such as those of Antarctica has significantly influenced the understanding of the molecular, physiological and behavioural mechanisms by which organisms adapt in order to survive, grow and reproduce under extreme conditions. The evolutionary origin of Antarctic crocodile icefish (Notothenioidei) can be dated back to the isolation of the Antarctic continent and the surrounding Southern Ocean (Oligocene/Miocene boundary, approx. 25 mya) by the opening of the Drake Passage and the formation of the Antarctic circumpolar current (ACC)

61 (Eastman, 1993; Near, Pesavento \& Cheng, 2003; Kock, 2005; Garofalo et al., 2009). This isolation gave rise to a roughly circular ocean front, the Antarctic Polar Front (APF), which acts as a climatic and biologic barrier and decouples the Southern Ocean surrounding Antarctica from warm subtropical waters further north. The extensive temperature decrease coupled with ice sheet expansion, following the opening of the Drake Passage, led to a process of selection by exposure to freezing conditions in resident communities. The extinction of a large part of the endemic fish fauna due to freezing intolerance fueled the evolution of cold-adapted species (Bargelloni et al., 1994; Wöhrmann, 1997; Kock, 2005; Cheng, di Prisco \& Verde, 2009; Near et al., 2012). This period of extreme cooling, ice sheet growth and formation of sea ice along the Antarctic continental shelf, together with little competition between species, is thought to be the period of strong 
72 suborder evolved from a benthic living ancestor endemic to Antarctica, which adapted to the cold

73 environment by the expression of antifreeze glycoproteins (AFGPs), finally radiated and

74 successfully occupied many ecological niches (Bargelloni et al., 1994; Near, 2004; Kock, 2005).

75 Today, the Notothenioidei strongly dominate the teleost fish diversity and abundance in the

76 Southern Ocean and account for $90 \%$ of the fish biomass and for over $50 \%$ of all fish species in

77 most regions of the Antarctic Sea (Wöhrmann, 1997; Flores et al., 2004; Kock, 2005; Reid et al.,

78 2007; Near et al., 2012). The suborder contains 130 species in eight families (Artedidraconidae,

79 Bovichtidae, Pseudaphritidae, Eleginopsidae, Nototheniidae, Harpagiferidae, Bathydraconidae,

80 Channichthyidae) (Near, Pesavento \& Cheng, 2003; Near et al., 2012).

81 Within the Notothenioidei, species of crocodile icefish (Channichthyidae) form a monophyletic

82 group and are, with regard to morphological characters, one of the most derived clades of the

83 Notothenioidae (Iwami, 1985; Near, Pesavento \& Cheng, 2003; Kock, 2005). While

84 Channichthyidae have been the focus of many studies dealing with their unique physiological

85 adaptations (e.g. their complete lack of the oxygen-binding haemoglobin) (see Sidell et al., 1997;

86 Feller \& Gerday, 1997; Garofalo et al., 2009), studies on their ecology are comparatively rare.

87 Parasites can function as biological indicators as they are directly linked to the food chain and can

88 provide valuable information on the ecology of the host. For instance, metazoan parasites, and

89 especially helminths, have evolved complex life-cycles, including several hosts among different

90 trophic levels, and are therefore deeply embedded within food webs. As a proxy for long-term

91 trophic interactions, their analyses increase the knowledge on the ecology of the hosts and their

92 linkage in the food web (Klimpel, Seehagen \& Palm, 2003; Lafferty et al., 2008) without the need

93 for great sampling efforts of the various trophic levels involved. 
94 In the present study, we aimed to analyze the parasite fauna and stomach contents of

95 Champsocephalus gunnari (Lönnberg, 1905), Chaenodraco wilsoni (Regan, 1914), Neopagetopsis

96 ionah (Nybelin, 1947), Pagetopsis macropterus (Boulenger, 1907), and Pseudochaenichthys

97 georgianus (Norman, 1937), all members of the family Channichthyidae. The effort was made to

98 increase our currently limited knowledge of their ecology and the host range of their associated

99 parasite fauna.

100

101 Materials \& Methods

102 Eighty channichthyid fish (Champsocephalus gunnari: $\mathrm{n}=25$, Chaenodraco wilsoni: $\mathrm{n}=33$,

103 Neopagetopsis ionah: $\mathrm{n}=3$, Pagetopsis macropterus: $\mathrm{n}=4$, Pseudochaenichthys georgianus: $\mathrm{n}=$

104 15) were collected and sorted on board of the German RV Polarstern during the research cruise

105 ANT-XXVIII/4 (2012) to the South Shetland Islands region, Elephant Island and the tip of the

106 Antarctic Peninsula (CCAML statistical subarea 48.1) (see Table 1, Fig. 1). Fishes were caught

107 with a bottom trawl (mouth opening: $2.5-3.2 \mathrm{~m} \mathrm{x} 16-18 \mathrm{~m}$ ) with a towing time of $30 \mathrm{~min}$. After

108 each haul fish species were identified according to Gon and Heemstra (1990) and sorted by species.

109 Individuals were packed in plastic bags, labelled and deep frozen at $-40{ }^{\circ} \mathrm{C}$ for subsequent

110 examination.

111

112 Parasitological examination and stomach content analysis

113 Total length (TL) and standard length (SL) were measured to the nearest millimetre and total

114 weight (TW) was measured to the nearest 1.0 g. Gills, nostrils, skin, fins, eyes, and mouth cavity

115 were examined for ectoparasites. Fish were then opened, the intestinal organs were removed, and

116 transferred separately into petri dishes filled with $0.9 \%$ saline solution. Liver (LG), gonads (GO), 
117 full (SW) and empty stomachs ( $\left.\mathrm{SW}_{\text {empty }}\right)$ were weighed to the nearest $0.1 \mathrm{~g}$. The liver, gonads,

118 stomach, gut, gall bladder, pyloric caeca were then dissected and microscopically examined for

119 endoparasites with a magnification of 6.7 - 45 x (Olympus SZ 61, Germany). Host tissue was

120 removed from isolated parasites. Digenea, Cestoda, Crustacea, and some nematodes were fixed in

$1214 \%$ borax buffered formalin and preserved in 70\% ethanol with $4 \%$ glycerol for morphological

122 identification. The remaining nematodes were preserved in EtOH (abs.) for subsequent molecular

123 identification. Stomach contents were removed from each fish and isolated food items were

124 separated and identified to the lowest possible taxon. Terminology for parasitological and

125 ecological examination followed Bush et al. (1997). Parasite species were morphologically

126 identified using original description as well as identification keys (e.g. Zdzitowiecki, 1991a;

127 Klöser \& Plötz, 1992; Zdzitowiecki, 1997; Rocka, 2004; Utevsky, 2005). In addition, randomly

128 chosen subsamples from nematode specimens were identified using molecular methods.

130 Molecular nematode identification

131 Genomic DNA was isolated and purified from 117 parasite larvae for nematode species

132 identification, using the peqGOLD Tissue DNA MicroSpin Kit (Peqlab Biotechnology GmbH,

133 Erlangen, Germany) according to the instructions of the manufacturer. An approx. $639 \mathrm{bp}$ long

134 fragment of the mitochondrial cytochrome oxidase 2 (cox2) region was amplified using the primers

135 211-F (5'-TTT TCT AGT TAT ATA GAT TGR TTY AT-'3) and 210-R (5'-CAC CAA CTC TTA

136 AAA TTA TC-3') (Nadler \& Hudspeth, 2000). The PCR-reaction (25 $\mu$ l) included $12.5 \mu 1$ Master-

137 Mix (Peqlab Biotechnology GmbH, Erlangen, Germany) containing dNTP (0.4 mM), $\mathrm{MgCl}_{2}(4$

$138 \mathrm{mM})$, Buffer (40mM Tris-HCL, 32mM $\left(\mathrm{NH}_{4}\right)_{2} \mathrm{SO}_{4}, 0.02 \%$ Tween 20) HotStart Taq-Polymerase

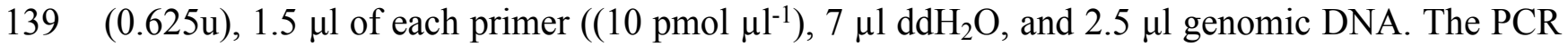


140 temperature and cycling parameters were: initial denaturation at $94^{\circ} \mathrm{C}$ for $180 \mathrm{sec}, 40$ cycles of

$14194^{\circ} \mathrm{C}$ for $30 \mathrm{sec}$ (denaturation), $46^{\circ} \mathrm{C}$ for $60 \mathrm{sec}$ (annealing), $72^{\circ} \mathrm{C}$ for $90 \mathrm{sec}$ (extension), followed

142 by a final extension at $72^{\circ} \mathrm{C}$ for $10 \mathrm{~min}$. Samples without DNA were included as negative controls

143 in each PCR run. PCR products were visualized on 1\% agarose gels. To estimate the size of the

144 PCR products, a 100bp ladder marker (peqGOLD, Erlangen, Germany) was used. Afterwards,

145 PCR products were purified with the peqGOLD Cycle-Pure Kit (Peqlab Biotechnology GmbH,

146 Erlangen, Germany) following the instructions of the manufacturer. The purified products were

147 sequenced by Seqlab (Goettingen GmbH, Germany) using primer 210-R.

148

149 Sequence Analyses

150 Analyses were performed using Geneious v.8.1.7. Sequence data were compared with previously

151 published Genbank data using a BLASTn search (Altschul et al., 1990). For phylogenetic

152 reconstruction, a multiple sequence alignment including the 117 obtained sequences as well as 19

153 previously annotated reference sequences of phylogenetically closely related anisakid species was

154 generated using MUSCLE as implemented in Geneious v.8.1.7 using default parameters

155 (Alignment S3).

156 Bayesian inference (BI) analysis was performed on the 634 base pair MUSCLE alignment using

157 MrBayes v3.1.2 (Huelsenbeck \& Ronquist, 2001) as implemented in Geneious v.8.1.7. The GTR

158 substitution model with gamma rate variation (5 categories) was used. Default parameters were

159 used for Markov Chain Monte Carlo (MCMC) parameters (chain length: 1,100,000; subsampling 160 frequency: 200; heated chains 4; heated chain temp: 0.2 burn-in length: 10,000; random seed:

$16131,049)$. A consensus tree was constructed from the tree output files after discarding the first 10\%

162 (support threshold: 50\%; burn-in: 10\%) and visualised using TreeGraph 2 (Stöver \& Müller, 2010). 
163 Anisakis simplex (s.s.) (Acc.No: KT852484) as a common and closely related taxon was included

164 as an outgroup.

165

166 Data analysis/statistics

167 Statistical analyses were conducted in $\mathrm{R}$ (version 3.0.2). Host biometric values, parasite

168 abundances and parasite intensities are given with standard deviation $( \pm \mathrm{SD})$. Parasite fauna

169 diversity was calculated using the Shannon-Wiener index $\left(H^{\prime}\right)$ and Pielous's evenness $\left(J^{\prime}\right)$

170 according to Magurran

171

172 In order to compare the parasitological findings of the examined specimens with other members

173 of the family Channichthyidae, data of metazoan parasites from the different species of this family

174 were collected by a search on Google Scholar and Web of Knowledge. The names of the known

175 channichthyid species, combined with the keywords "parasite" "Digenea", "Monogenea",

176 "Cestoda", "Nematoda", “Acanthocephala", and "Crustacea" were used. In addition to original

177 publications, Klimpel et al. (2009) and Oguz et al. (2015) were taken into consideration. Validity

178 of species names were checked by using The World Register of Marine Species

179 (www.marinespecies.org). Only unambiguous records were included. The results are given in

180 Table S1.

181

\section{Results}

183 Parasite infection data

184 A total of 2563 individual parasites was isolated from the 80 samples of channichthyid fishes

185 belonging to 14 different genera and 15 species, including 15 new host records (Table 2, 3, S2). 
186 Parasites belonged to the six taxonomic groups Digenea (4 species), Nematoda (4), Cestoda (2),

187 Acanthocephala (1), Hirudinea (3), and Copepoda (1) (Table 2, 3, Fig. 2). Pseudochaenichthys

188 georgianus had the highest number of parasite species with 13 species belonging to six different

189 taxa, followed by Chaenodraco wilsoni (7 species), while numbers of parasite species of

190 Champsocephalus gunnari (4), Neopagetopsis ionah (3), and P. macropterus (4) were

191 comparatively low. The predominant species were postlarval diphyllobothriidean cestodes and the

192 larval nematodes Contracaecum osculatum and C. radiatum, which occurred in all five host

193 species with overall prevalences of $35 \%, 55 \%$, and $45 \%$, respectively.

194

195 Stomach content analysis

196 There were no pronounced differences in diet composition of the five examined fish species (Table

197 4). $71.25 \%(\mathrm{n}=57)$ of fish stomachs contained prey items (C. wilsoni: $69.7 \%$, C. gunnari: $96.0 \%$;

198 N. ionah: 66.7\%; P. macropterus: 100\%; P. georgianus: 26.7\%). Only Crustacea were found

199 among all stomach samples. Due to the frequently advanced state of digestion, only a minor part

200 could be identified to a lower taxonomic level. Prey items that could be further identified belonged

201 to the order Euphausiacea, which constituted an average abundance of $70.2 \%$ with a numerical

202 percentage of prey $(\mathrm{N})$ ranging from 37.8 to $90.5 \%$, mostly of the genus Euphausia sp., and an

203 average frequency of occurrence of $\mathrm{F}_{[\%]}=54.2$ ranging from 25.0 to $83.3 \%$. On the species level,

204 Euphausia superba was identified in fish of $C$. wilsoni and $C$. gunnari with $\mathrm{F}_{[\%]}=30.4 \%$ and

$205 \mathrm{~F}_{[\%]}=54.2$, respectively. Single specimens of the order Amphipoda were only found in C. gunnari, 206 with $\mathrm{F}_{[\%]}=8.3$.

207

208 Molecular nematode identification 
209 The 117 obtained sequences using BLASTn-analyses showed highest congruence with eight

210 different sequences that could not all be annotated to a species level in GenBank (Table S3). The

211 vast majority (100 sequences) belonged to the genus Contracaecum with Contracaecum cf.

212 osculatum D (31) and C. cf. osculatum E (28) being the dominant genotypes. Contracaecum

213 radiatum (14) and Contracaecum osculatum (s.l.) (8) were identified, and 16 individuals that were

214 assigned to Contracaecum sp.. Three sequences were assigned to Contracaecum aff.

215 multipapillatum A and one sequence was identified as Pseudoterranova decipiens. Interestingly,

21616 sequences could not be assigned to any of the anisakid genera present in the Antarctic and

217 showed highest similarity (approx. 85\%) to the ascarid Parasascaris equorum.

218

219 Phylogenetic analyses

220 A total of 138 Operational Taxonomic Units were included in the final dataset. In order to further

221 identify the taxonomic status of the anisakid nematode sequences obtained, a set of 18 reference

222 anisakid sequences of known identity (Pseudoterranova krabbei HM147279; P. decipiens (s.s.)

223 HM147278; P. decipiens E HM147282; P. cystophorae EU477209; P. ceticola DQ116435; P.

224 cattani KC782949; P. bulbosa HM147280; P. azarasi HM147281; Contracaecum radiatum

225 EU477210, C. osculatum (s.s.) EU477206; C. osculatum E EU477207; C. osculatum D

226 EU477205; C. osculatum B EU477404; C. osculatum A EU477203; C. osculatum baicalensis

227 EU477208; C. ogmorhini (s.s.) EU477211; C. mirounga EU477213; C. margolisi EU477212)

228 were included in the phylogenetic reconstruction (Fig. 3). Anisakis simplex s.s. (KX158869) was

229 used as an outgroup. Most of the sequences clustered within clades that are in accordance with the

230 species identification via BLASTn (Fig. 3). The only sequence of Pseudoterranova decipiens

231 (Pg_11_4b) clustered as a sister clade with Pseudoterranova decipiens E. Six individuals that were 
232 identified as Contracaecum sp. were grouped within the same clade as C. mirounga. The three

233 sequences that showed low identity with Contracaecum aff. multipapillatum A clustered together

234 with the 16 sequences of "Parascaris equorum" as a monophyletic sister clade of C. margolisi

235 and C. ogmorhini (s.s.).

236

237 Discussion

238 Overall, fifteen metazoan parasite species of thirteen different genera were identified. Among the

239 detected parasite species, nine and six species were present as larval or adult stages, respectively,

240 with larval parasites showing high infestation rates. Generally, adult stages would indicate the fish

241 as the final host for the parasite species, whereas larval stages are found in intermediate hosts

242 feeding on zooplankton. Pseudochaenichthys georgianus showed the highest diversity with

243 thirteen different parasite species. This high number of taxa might reflect the feeding behavior, life

244 style and zone preference of the fish, ranging from benthic to pelagic (Iwami \& Kock, 1990). The

245 other four fish species had a less diverse fauna. Compared to other members of the suborder

246 Notothenioidei (e.g. Dissostichus eleginoides (47 parasites species), Macrourus whitsoni (25),

247 Notothenia coriiceps (37) (Palm et al., 1998; Klimpel et al., 2009; Münster et al., 2016)) this is a

248 rather low parasite diversity, found within this study (see also Table S1). Among the sampled

249 species, Cestoda (postlarvae) were the dominant parasite groups in terms of prevalence and 250 intensity. Cestoda often use Antarctic elasmobranchs and birds as final hosts (Rocka, 2017). For

251 nematodes, except for Ascarophis nototheniae, Channichthyidae serve as intermediate hosts and

252 marine mammals as final hosts and occurred as L3-larvae in the examined fishes. In the case of

253 the genera Pseudoterranova and Contracaecum, the main final hosts are Pinnipedia, (Klöser et al.,

254 1992; McClelland, 2002), just like the only acanthocephalan Corynosoma bullosum, which was 
255 isolated from P. georgianus, matures in a pinniped host (e.g. Mirounga leonine) (Zdzitowiecki,

256 1991a). These findings emphasize the role of Channichthyidae as important intermediate hosts,

257 mostly preying on crustaceans infected with larval stages. The low infection parameters

258 (prevalence and intensity) and diversity of Digenea is surprising as they are probably the most

259 diverse metazoan parasite group within Antarctic waters (Rocka, 2006). Whether seasonal

260 variations of abundances, as assumed to occur in some digenean species (Rohde, 2005), might

261 have influenced these numbers cannot be evaluated due to a lack of comparable studies taken

262 during the austral winter. Another explanation could be the high abundance of Euphausiacea in

263 these waters, which are not known to harbor larval digeneans. The low diversity is in accordance

264 to the findings in previous studies (Table S1).

265 In the following we are going to discuss the fish according to their ecology.

266 Champsocephalus gunnari and Chaenodraco wilsoni

267 A high similarity of C. wilsoni and C. gunnari (81.6\%) was revealed and might be explained by

268 the fact that these two species share a similar food spectrum, including almost exclusively

269 Crustacea. Chaenodraco wilsoni complements its diet with other small crustaceans such as the

270 Euphausiacea Thysanoessa macrura, Amphipoda (Themisto gaudichaudii), and occasionally small

271 fish (Pleuragramma antarctica) whereas Chaenodraco wilsoni includes also Hyperiidea and

272 Mysida (Iwami \& Kock, 1990; Eastman, 1993; Kock et al., 1994; Frolkina, 2002; Flores et al.,

273 2004; Kock, 2005; Kock et al., 2008; Kock, Gröger \& Jones, 2013). Stomach content analyses of

274 the present study support previous investigations, with food items mainly consisting of

275 Euphausiacea, which in some cases could be identified as Euphausia superba. No residues of fish

276 species were found, which supports the role of $C$. wilsoni and C. gunnari as highly specialized on

277 krill. Parasite diversity and infection parameters are also in accordance with the postulated feeding 
278 ecology of the species. Parasite species diversity was low and consisted of mainly larval cestodes

279 (Diphyllobothriidea indet.), nematodes (Contracaecum osculatum, C. radiatum, Contracaecum

280 sp., Nematoda indet.) and one digenean species (C. gunnari: Macvicaria georgiana; C. wilsoni:

281 Neolebouria antarctica). These parasites use fish as second intermediate or paratenic hosts.

282 Macvicaria georgiana and Neolebouria antarctica were present in the adult stage, respectively,

283 indicating the role of the fish as final hosts in the life cycle of these digenean parasites.

284 Digenea are mainly present in coastal zones of Western Antarctica while they are scarce in the 285 open sea and deep waters. Especially in the Weddell Sea and around the South Shetland Islands 286 this parasite taxon is rare and particularly the species $N$. antarctica shows a low abundance in this 287 area compared to other Antarctic regions (South Georgia) (Zdzitowiecki, 1991b, 1997; Rocka, 288 2006; Oguz et al., 2012). Representatives of the order Diphyllobothriidea are commonly known to 289 infect zooplankton (i.e. Euphausia superba) as first intermediate host and are frequently found 290 around the South Shetland Islands in channichthyid representatives (Kock, 1992; Rocka, 2003, 291 2006; Palm, Klimpel \& Walter, 2007; Oguz et al., 2012). Due to the fact that exclusively 292 plerocercoid larval stages were present $C$. gunnari and C. wilsoni can be considered intermediate 293 hosts.

294 The most prominent parasites in prevalence and intensity were the Nematoda with the larval stages 295 (L3) of the species Contracaecum osculatum and C. radiatum which both infect seals (e.g. 296 Leptonychotes weddellii, in this region) as a final host (Klöser et al., 1992). Channichthyids are

297 known to occupy a key position in the life cycle of Antarctic Contracaecum (Kock, 1992; Oguz et 298 al., 2012). The present study reveals a slightly higher prevalence and intensity of C. osculatum 299 than of C. radiatum. This observation is contrary to the assumption, that $C$. radiatum developed a 300 pelagic life cycle and therefore shows a higher abundance in pelagic fish species. On the contrary, 
301 C. osculatum developed a benthic life cycle (Klöser et al., 1992; Kock, 1992; Palm et al., 1994).

302 Contradicting observations of the present study can be explained by the targeted host species. Even

303 if representatives of the Channichthyidae play a key role in the life cycle of Antarctic

304 Contracaecum, both fish might be representatives of lower importance. Contracaecum radiatum

305 is highly abundant in piscivorous channichthyids like Chaenocephalus aceratus, C. rhinoceratus

306 and $C$. dewitti that feed on pelagic Pleurogramma antarcticum (Klöser et al., 1992; Kock, 1992;

307 Palm et al., 1994).

308

309 Neopagetopsis ionah and Pagetopsis macropterus

310 Reliable data on the feeding behaviour of Neopagetopsis ionah and Pagetopsis macropterus are

311 scarce. The food spectrum is described as a mixture of euphausiids, copepods, pteropods, and fish

312 where the proportion of different items in the diet varies greatly with time and space (Kock, 1992;

313 Eastman, 1993; Kock, 2005; Kock, Gröger \& Jones, 2013). Stomach content analyses of the

314 present study revealed only food items belonging to the Crustacea (Table 4). More precisely

315 identified residues were assigned to the order Euphausiacea or the genus Euphausia. No residues

316 of copepods, pteropods or fish were found. The absence of these food items could be explained by

317 the fact that individuals around the South Shetland Islands prey preferential on euphausiids as this

318 taxon is strongly represented and provides a high biomass in this region (Ichii, Naganobu \&

319 Ogishima, 1996; Reiss et al., 2008).

320 Parasitological findings are in accordance with stomach content analyses but contradict literature

321 data which describe $N$. ionah as piscivorous (Iwami \& Kock, 1990; Kock, 1992, 2005; Eastman,

322 1993; Kock, Gröger \& Jones, 2013). Present stomach content and parasitological investigations

323 indicate a diet mainly based on krill and other crustaceans for $N$. ionah. Compared to the other 
324 four channichthyid species, Pagetopsis macropterus showed higher intensities of the three

325 endoparasites Diphyllobothriidea indet., Contracaecum osculatum and C. radiatum. In relation to

326 the literature about the feeding ecology, these higher parasite intensities could be explained by a

327 piscivorous feeding of $P$. macropterus which leads to an accumulation of parasites via the prey

328 (Kock, 1992; Williams, MacKenzie \& McCarthy, 1992; Klimpel, Seehagen \& Palm, 2003; Palm,

329 Klimpel \& Walter, 2007). Because parasite intensity and diversity integrates the feeding ecology

330 for a longer period, in the case of $P$. macropterus, it is more likely, that the fish species principally

331 has a diet including fish. However, this could not be verified by stomach content analyses. Thus,

332 it was not possible to contradict the hypothesis of a principally piscivorous diet in the species. The

333 small sample size for both species is not representative in order to interpret the feeding behavior.

Pseudochaenichthys georgianus

336 Like Neopagetopsis ionah and Pagetopsis macropterus, the food spectrum of Pseudochaenichthys

337 georgianus includes Crustacea and fish, with the proportion of the different items varying in time 338 and space (Kock, 1992, 2005; Eastman, 1993; Kock, Gröger \& Jones, 2013). Similar to the former two species it is possible, that individuals of $P$. georgianus around the South Shetland Islands prey

340 intensively on krill because of its high abundance. The problem of contradictions in parasitological

341 findings and stomach content analyses in P. georgianus are similar to P. macropterus.

342 Endoparasite diversity and intensity of $P$. georgianus was high and greatly exceeded parasite 343 parameters of the other four fish species. Similar to the previous four species the cestode

344 Diphyllobothriidea indet. and the nematode species C. osculatum, C. radiatum and Contracaecum 345 sp. were isolated in the larval stage. In addition, high numbers of the cestode Tetraphyllidae indet.

346 and the nematode $P$. decipies were detected. For both taxa $P$. georgianus serves as a second 
347 intermediate or paratenic host. Final host for Tetraphyllidae indet. are elasmobranchs, while

348 representatives of Pseudoterranova are parasites of marine mammals. High prevalence and

349 parasite intensity in $P$. georgianus (Table 2 ) points to a strong accumulation of parasites through

350 a piscivorous or unspecialized feeding behaviour. In contrast to the other four channichthyid

351 species, $P$. georgianus was infected with a species belonging to the acanthocephalans.

352 Corynosoma bullosum infects marine fish as intermediate host, mammals or birds act as final hosts

353 (Zdzitowiecki, 1991a). Corynosoma bullosum occurred in the cystacanth stage of development in

354 P. georgianus. The life cycle of Acanthocephalans is largely linked to the benthic environment,

355 and the group is rarely found in planktonic organisms (Marcogliese, 1995). Thereby benthic

356 amphipods and ostracods are used as first intermediate hosts. Fish that exploit the bottom layer are

357 therefore commonly used as second intermediate or final host, depending on the acanthocephalan

358 species (Zdzitowiecki, 1991a; Kock, 1992; Rocka, 2006; Palm, Klimpel \& Walter, 2007). The

359 occurrence of this parasite in $P$. georgianus gives therefore more information about the horizontal

360 distribution of its host than about the diet.

361

362 Molecular analyses of nematodes

363 Molecular analyses of a subsample of anisakid nematodes and the subsequent phylogenetic

364 reconstructions were conducted in order to confirm previous morphological identification and

365 identify the nematodes to (sibling) species level.

366 While GenBank analyses did not provide sufficient resolution for identification to species level

367 (e.g. Contracaecum sp., Nematoda indet.), phylogenetic reconstruction including a set of 18

368 reference species allowed a more accurate species assignment. Analyses clearly revealed the

369 species Contracaecum osculatum (sensu lato), which splits into the two sibling species $C$. 
370 osculatum D and C. osculatum E. Another nematode species, Contracaecum radiatum, was

371 identified by molecular investigations (Table S2). No sibling species of C. radiatum are known.

372 The parasite species is known to be distributed in the Southern Ocean and occurs in high numbers

373 around Antarctica. Representatives of the Channichthyidae are also known to be infested with

374 larval forms of C. radiatum (Klöser et al., 1992; Kock, 1992; Arduino et al., 1995; Mattiucci \&

375 Nascetti, 2007; Palm, Klimpel \& Walter, 2007).

376 The species Pseudoterranova decipiens (s.l.) was identified which supports previous

377 investigations in the Antarctic region (Palm et al., 1994; Zhu et al., 2002; Palm, Klimpel \& Walter,

378 2007; Timi et al., 2014). Only one sequence was obtained and it was assigned to the species $P$.

379 decipiens $\mathrm{E}$, a sibling species of the $P$. decipiens complex known from Antarctic waters. It differs

380 genetically from the four-other species of the complex (P. bulbosa, P. azarasi, P. krabbei, P.

381 cattani) from the North Atlantic, Norwegian Sea, Baltic Sea and Arctic-Boreal and Japanese

382 waters (Zhu et al., 2002; Mattiucci \& Nascetti, 2007; Timi et al., 2014). Previous studies included,

383 it can be assumed that all individuals of $P$. decipiens found in this study belong to the sibling

384 species $P$. decipiens E. However, further investigations based on the cox 2 marker are needed to

385 verify this assumption. Pseudoterranova was only found in representatives of the host species

386 Pseudochaenichthys georgianus and could not be detected in any of the other targeted fish species.

387 Sixteen nematode samples revealed similar sequences using sequence analysis, but could not be

388 clearly assigned to existing sequences in GenBank (Fig. 3, Table S3). These samples came

389 exclusively from nematodes found in the host species Chaenodraco wilsoni and Champsocephalus

390 gunnari. Sequence analyses (BLASTn) showed the highest sequence identity to a phylogenetically

391 related species annotated as Parascaris equorum in GenBank. This equine ascarid nematode is

392 an important cosmopolitan in foals (Lindgren et al., 2008). Species like this or closely related ones 
393 have no affiliation to the marine or Antarctic environment in any life stage and were never found

394 in this region. This excludes the occurrence of individuals of this species in representatives of the

395 Channichthyidae. This is also supported by the low sequence identity of the GenBank comparison

396 (83-85 \%, Table S3). The relevant sequences form a separate clade including also those sequences

397 that have been identified as Contracaecum aff. multipapillatum A before. These results indicate

398 that the sequences might belong to a species of Contracaecum that have not been annotated before.

399 Further investigations are needed in order to clarify their taxonomic status.

400

401 Conclusion

402 Although Channichthyidae have been extensively studied, only few have dealt with the ecology or

403 the parasite fauna. The large number of 15 new host records found in this study shows the

404 importance of studies within Antarctic water to gain a better understanding of this unique habitat.

405 Most recorded parasite species can be characterized by a broad host range including a variety of 406 different Notothenioidei, emphasizing their important role as hosts in the Southern Ocean.

407 Furthermore, a possible new genotype or even species might exist among the nematodes.

408

409 Acknowledgements

410 We thank Karl-Hermann Kock, Volker Siegel and Christopher Jones for their contributions during

411 the field work on the RV Polarstern and we gratefully acknowledge Birgit Nagel for her technical

412 assistance.

413

\section{References}


415 Altschul SF., Gish W., Miller W., Myers EW., Lipman DJ. 1990. Basic local alignment search 416 tool. Journal of Molecular Biology 215:403-410.

417 Arduino P., Nascetti G., Cianchi R., Plötz J., Mattiucci S., D’Amelio S., Paggi L., Orecchia P., 418 Bullini L. 1995. Isozyme variation and taxonomic rank of Contracaecum radiatum (v. 419 Linstow, 1907) from the Antarctic Ocean (Nematoda, Ascaridoidea). Systematic Parasitology 30:1-9.

421 Bargelloni L., Ritchie PA., Patarnello T., Battaglia B., Lambert DM., Meyer A. 1994. Molecular 422 423 Molecular Biology and Evolution 11:854-863.

425 426 428 evolution at subzero temperatures: mitochondrial and nuclear phylogenies of fishes from Antarctica (suborder Notothenioidei), and the evolution of antifreeze glycopeptides.

Bush AO., Lafferty KD., Lotz JM., Shostak AW. 1997. Parasitology meets ecology on its own terms: Margolis et al. revisited. The Journal of Parasitology:575-583.

Cheng C-HC., di Prisco G., Verde C. 2009. Cold-adapted Antarctic fish: the discovery of neuroglobin in the dominant suborder Notothenioidei. Gene 433:100-101.

Eastman JT. 1993. Antarctic fish biology: evolution in a unique environment. San Diego: Academic Press.

Feller G., Gerday C. 1997. Adaptations of the hemoglobinless Antarctic icefish (Channichthyidae) to hypoxia tolerance. Comparative Biochemistry and Physiology Part A: Physiology 118:981-987. DOI: 10.1016/S0300-9629(97)86786-2.

Flores H., Kock K-H., Wilhelms S., Jones CD. 2004. Diet of two icefish species from the South Shetland Islands and Elephant Island, Champsocephalus gunnari and Chaenocephalus aceratus. Polar Biology 27:119-129.

Froese R., Pauly D. 2016. FishBase. Available at http: |lwww.fishbase.org. 
438 Frolkina ZA. 2002. Distribution of mackerel icefish (Champsocephalus gunnari)

(Channichthyidae) around South Georgia at various stages of its life cycle. CCAMLR

440 Science 9:49-69.

441 Garofalo F., Pellegrino D., Amelio D., Tota B. 2009. The Antarctic hemoglobinless icefish, fifty 442 five years later: A unique cardiocirculatory interplay of disaptation and phenotypic plasticity. Comparative Biochemistry and Physiology Part A: Molecular \& Integrative Physiology 154:10-28. DOI: 10.1016/j.cbpa.2009.04.621.

Huelsenbeck JP., Ronquist F. 2001. MRBAYES: Bayesian inference of phylogenetic trees.

Gon O., Heemstra PC. 1990. Fishes of the southern ocean. Grahamstown: JLB Smith Institute of Ichthyology. Bioinformatics 17:754-755.

Ichii T., Naganobu M., Ogishima T. 1996. Competition between the krill fishery and penguins in the South Shetland Islands. Polar Biology 16:63-70.

451

452

453

454

455

456

457 458

459

Iwami T. 1985. Osteology and relationships of the family Channichthyidae. Memoirs of National Institute of Polar Research. Series E, Biology and Medical Science 36:1-69.

Iwami T., Kock KH. 1990. Channichthyidae. In: Gon O., Heemstra PC., eds. Fishes of the Southern Ocean. Grahamstown: JLB Smith Institute of Ichthyology, 381-399.

Klimpel S., Busch MW., Kellermanns E., Kleinertz S., Palm HW. 2009. Metazoan Deep Sea Fish Parasites. Solingen: Verlag Natur \& Wissenschaft.

Klimpel S., Seehagen A., Palm HW. 2003. Metazoan parasites and feeding behaviour of four small-sized fish species from the central North Sea. Parasitology Research 91:290-297. DOI: $10.1007 / \mathrm{s} 00436-003-0957-8$. 
460 Klöser H., Plötz J. 1992. Morphological distinction between adult Contracaecum radiaturn and 461 Contracaecum osculatum (Nematoda, Anisakidae) from the Weddell seal (Leptonychotes 462 463 weddelli). Zoologica Scripta 21:129-132. DOI: 10.1111/j.1463-6409.1992.tb00315.x.

Klöser H., Plötz J., Palm H., Bartsch A., Hubold G. 1992. Adjustment of anisakid nematode life cycles to the high Antarctic food web as shown by Contracaecum radiatum and $C$. osculatum in the Weddell Sea. Antarctic Science 4:171-178.

Kock K-H. 1992. Antarctic fish and fisheries. Cambridge: Cambridge University Press.

Kock K-H. 2005. Antarctic icefishes (Channichthyidae): a unique family of fishes. A review, Part I. Polar Biology 28:862-895.

Kock K-H., Gröger J., Jones CD. 2013. Interannual variability in the feeding of ice fish (Notothenioidei, Channichthyidae) in the southern Scotia Arc and the Antarctic Peninsula region (CCAMLR Subareas 48.1 and 48.2). Polar Biology 36:1451-1462. DOI: 10.1007/s00300-013-1363-z.

Kock K-H., Pshenichnov L., Jones CD., Gröger J., Riehl R. 2008. The biology of the spiny icefish Chaenodraco wilsoni Regan, 1914. Polar Biology 31:381-393. DOI: 10.1007/s00300-007-0366-Z.

Kock KH., Wilhelms S., Everson I., Groger J., others 1994. Variations in the diet composition and feeding intensity of mackerel icefish Champsocephalus gunnari at South Georgia PT., Kuris AM., Marcogliese DJ., Martinez ND., Memmott J., Marquet PA., McLaughlin JP., Mordecai EA., Pascual M, Poulin R, Thieltges DW. 2008. Parasites in food webs: the ultimate missing links. Ecology Letters 11:533-546. 
483 Lindgren K., Ljungvall Ö., Nilsson O., Ljungström B-L., Lindahl C., Höglund J. 2008.

484

485

486

487

488

489

490

491

492

493

494

495

496

497

498

499

500

501

502

503

504

Parascaris equorum in foals and in their environment on a Swedish stud farm, with notes on treatment failure of ivermectin. Veterinary Parasitology 151:337-343.

Magurran AE. 1988. Why diversity? In: Ecological Diversity and Its Measurement. Dordrecht: Springer, , 1-5. DOI: 10.1007/978-94-015-7358-0_1.

Marcogliese DJ. 1995. The role of zooplankton in the transmission of helminth parasites to fish. Reviews in Fish Biology and Fisheries 5:336-371.

Mattiucci S., Nascetti G. 2007. Genetic diversity and infection levels of anisakid nematodes parasitic in fish and marine mammals from Boreal and Austral hemispheres. Veterinary Parasitology 148:43-57.

McClelland G. 2002. The trouble with sealworms (Pseudoterranova decipiens species complex, Nematoda): a review. Parasitology 124:183-203.

Münster J., Kochmann J., Klimpel S., Klapper R., Kuhn T. 2016. Parasite fauna of Antarctic Macrourus whitsoni (Gadiformes: Macrouridae) in comparison with closely related macrourids. Parasites \& Vectors 9:403. DOI: 10.1186/s13071-016-1688-x.

Nadler SA., Hudspeth DS. 2000. Phylogeny of the Ascaridoidea (Nematoda: Ascaridida) based on three genes and morphology: hypotheses of structural and sequence evolution. Journal of Parasitology 86:380-393.

Near TJ. 2004. Estimating divergence times of notothenioid fishes using a fossil-calibrated molecular clock. Antarctic Science 16:37-44.

Near TJ., Dornburg A., Kuhn KL., Eastman JT., Pennington JN., Patarnello T., Zane L., Fernández DA., Jones CD. 2012. Ancient climate change, antifreeze, and the 

Sciences 109:3434-3439. DOI: 10.1073/pnas.1115169109.

507 Near TJ., Pesavento JJ., Cheng C-HC. 2003. Mitochondrial DNA, morphology, and the 508 phylogenetic relationships of Antarctic icefishes (Notothenioidei: Channichthyidae). $509 \quad$ Molecular Phylogenetics and Evolution 28:87-98.

510 Oguz MC., Heckmann RA., Cheng CC., El-Naggar A., Tepe Y. 2012. Ecto and endoparasites of 511 some fishes from the Antarctic region. Scientia Parasitologica 13:119-128.

512 Oguz MC., Tepe Y., Belk MC., Heckmann RA., Aslan B., Gurgen M., Bray RA., Akgul U.

513 2015. Metazoan Parasites of Antarctic Fishes. Turkish Journal of Parasitology 39:174514 178. DOI: $10.5152 / \mathrm{tpd} .2015 .3661$.

515 Palm H., Andersen K., Klöser H., Plötz J. 1994. Occurrence of Pseudoterranova decipiens 516 (Nematoda) in fish from the southeastern Weddell Sea (Antarctic). Polar Biology 14:539-544.

518 Palm HW., Klimpel S., Walter T. 2007. Demersal fish parasite fauna around the South Shetland Islands: high species richness and low host specificity in deep Antarctic waters. Polar Biology 30:1513-1522.

521 Palm HW., Reimann N., Spindler M., Plötz J. 1998. The role of the rock cod Notothenia coriiceps Richardson, 1844 in the life-cycle of Antarctic parasites. Polar Biology 19:399523 406.

524 Reid WD., Clarke S., Collins MA., Belchier M. 2007. Distribution and ecology of 525 Chaenocephalus aceratus (Channichthyidae) around South Georgia and Shag Rocks 526 (Southern Ocean). Polar Biology 30:1523-1533. 
527 Reiss CS., Cossio AM., Loeb V., Demer DA. 2008. Variations in the biomass of Antarctic krill

528 (Euphausia superba) around the South Shetland Islands, 1996-2006. ICES Journal of $529 \quad$ Marine Science 65:497-508.

530 Rocka A. 2003. Cestodes of the Antarctic fishes. Polish Polar Research 24:261-276.

531 Rocka A. 2004. Nematodes of the Antarctic fishes. Polish Polar Research 25:135-152.

532 Rocka A. 2006. Helminths of Antarctic fishes: Life cycle biology, specificity and geographical 533 distribution. Acta Parasitologica 51:26-35.

534 Rocka A. 2017. Cestodes and Nematodes of Antarctic Fishes and Birds. In: Biodiversity and 535 Evolution of Parasitic Life in the Southern Ocean. Springer, 77-107.

536 Rohde K. 2005. Marine parasitology. Wallingford: CABI Publishing.

537 Sidell BD., Vayda ME., Small DJ., Moylan TJ., Londraville RL., Yuan M-L., Rodnick KJ., 538 Eppley ZA., Costello L. 1997. Variable expression of myoglobin among the hemoglobinless Antarctic icefishes. Proceedings of the National Academy of Sciences

541 Stöver BC., Müller KF. 2010. TreeGraph 2: Combining and visualizing evidence from different phylogenetic analyses. BMC Bioinformatics 11:7. DOI: 10.1186/1471-2105-11-7.

543 Timi JT., Paoletti M., Cimmaruta R., Lanfranchi AL., Alarcos AJ., Garbin L., GeorgeNascimento M., Rodríguez DH., Giardino GV., Mattiucci S. 2014. Molecular identification, morphological characterization and new insights into the ecology of larval Pseudoterranova cattani in fishes from the Argentine coast with its differentiation from the Antarctic species, $P$. decipiens sp. E (Nematoda: Anisakidae). Veterinary Parasitology 199:59-72. DOI: 10.1016/j.vetpar.2013.09.033. 
549 Utevsky AY. 2005. An identification key to Antarctic fish leeches (Hirudinea: Piscicolidae).

$550 \quad$ Ukrainian Antarctic Journal 3:135-144.

551 Williams HH., MacKenzie K., McCarthy AM. 1992. Parasites as biological indicators of the

552

553

554

555

556

557

558

559

560

561

562

563

564

565

566

567 population biology, migrations, diet, and phylogenetics of fish. Reviews in Fish Biology and Fisheries 2:144-176. DOI: 10.1007/BF00042882.

Wöhrmann APA. 1997. Gefierschutzsubstanzen bei Fischen der Polarmeere und ihre Bedeutung für Evolution und Ökologie. Polarforschung 65:27-40.

Zdzitowiecki K. 1991a. Antarctic acanthocephala. In: Wägele JW., Sieg J., eds. Synopses of the Antarctic Benthos. Koenigstein: Koeltz Scientific Books, 1-116.

Zdzitowiecki K. 1991b. Occurrence of digeneans in open sea fishes off the South Shetland Islands and South Georgia, and a list of fish digeneans in the Antarctic. Polish Polar Research 12:55-72.

Zdzitowiecki K. 1997. Antarctic Digenea, parasites of fishes. In: Wägele JW., Sieg J., eds. Synopses of the Antarctic Benthos. Koenigstein: Koeltz Scientific Books, 1-156.

Zhu XQ., D’amelio S., Palm HW., Paggi L., George-Nascimento M., Gasser RB. 2002. SSCPbased identification of members within the Pseudoterranova decipiens complex (Nematoda: Ascaridoidea: Anisakidae) using genetic markers in the internal transcribed spacers of ribosomal DNA. Parasitology 124:615-623. 


\section{Table legends}

569 Table 1: Trawl and catch data. Information on date, position ( $\mathrm{S}=$ south, $\mathrm{W}=$ west $)$ and depth

$570[\mathrm{~m}]$ are given for each station. For some trawls data about the duration or position were missing

571 (n.d). The number of individuals caught [n] is given for each species (C. g. = Champsocephalus

572 gunnari, $C$. ..$=$ Chaenodraco wilsoni, N. i. = Neopagetopsis ionah, P. m. = Pagetopsis

573 macropterus, $P$. g. = Pseudochaenichthys georgianus $)$.

574 Table 2: Parasitological data from the examined channichthyid Pseudochaenichthys

575 georgianus. $\mathrm{A}=$ adult $\mathrm{Lv}=$ larval; $\mathrm{BC}=$ body cavity, $\mathrm{L}=$ liver, $\mathrm{S}=$ stomach, $\mathrm{I}=$ intestine, $\mathrm{P}=$

576 pylorus, $\mathrm{FT}=$ fat tissue, $\mathrm{SU}=$ surface, $\mathrm{MC}=$ mouth cavity, $\mathrm{G}=$ gills; $\mathrm{n}=$ total number of

577 parasites, Location $=$ location of the parasite inside the host, $\mathrm{P}[\%]=$ prevalence, $\mathrm{MI}=$ mean

578 intensity, $\mathrm{I}=$ intensity (in parantheses), $\mathrm{MA}=$ mean abundance, $\mathrm{H}^{\prime}=$ diversity index, $\mathrm{J}^{\prime}=$

579 eveness. Parasites isolated from stomach and intestine, were located in the lumen of these

580 organs. New host records are marked with an asterisk $(*)$.

581 Table 3: Parasitological data from the examined channichthyids Chaenodraco wilsoni,

582 Chamsocephalus gunnari, Neopagetopsis ionah, and Pagetopsis macropterus. A = adult; Lv =

583 larval; $\mathrm{BC}=$ body cavity, $\mathrm{L}=$ liver, $\mathrm{S}=$ stomach, $\mathrm{I}=$ intestine, $\mathrm{P}=$ pylorus, $\mathrm{FT}=$ fat tissue, $\mathrm{SU}=$

584 surface, $\mathrm{MC}=$ mouth cavity, $\mathrm{G}=$ gills, $\mathrm{n}=$ total number of parasites, Location = location of the

585 parasite inside the host, $\mathrm{P}[\%]=$ prevalence, $\mathrm{MI}=$ mean intensity, $\mathrm{I}=$ intensity (in parantheses),

$586 \mathrm{MA}=$ mean abundance, $\mathrm{H}^{\prime}=$ diversity index, $\mathrm{J}^{\prime}=$ eveness. Parasites isolated from stomach and

587 intestine were located in the lumen of these organs. New host records are marked with an asterisk $588(*)$. 
589 Table 4: Food items isolated from the five channichthyid species. F[\%]: frequency of

590 occurrence; $\mathrm{N}[\%]$ : numerical percentage of prey; $\mathrm{W}[\%]$ : weight percentage of prey; IRI: index of

591 relative importance.

592

593 Figure captions

594 Fig. 1: Sampling locations off the Antarctic Peninsula. Specific information on coordinates of 595 the stations (1-8) are summarized in Table 1. Map data C Esri, DeLorme, GEBCO, NOAA, 596 NGDC.

597 Fig. 2: Relative composition of parasite taxa found in five channichthyid fish species. Results 598 are based on parasite prevalence. Cestoda and Nematoda were present in all examined fish species. 599 White: Digenea, light grey: Cestoda, medium grey: Acanthocephala, grey dots: Nematoda, dark 600 grey: Hirudinea, black: Crustacea.

601 Fig. 3: Phylogenetic tree of nematode sequences. Phylogenetic reconstruction of 117 obtained 602 sequences and 19 anisakid reference species. Branch support values are given for the consensus 603 tree constructed from 9902 original raw trees. For sample abbreviations please see Table S3. The 604 following sample-coding was used: "Species initials_Host-Nr._Nematode-No.”. GenBank 605 accession number were given for reference Sequences.

606

607 Supplementary

608 Table S1: Parasite fauna of channichthyid species, based on literature data and own studies.

609 Species occurring outside of the Antarctic Convergence (e.g. South Georgia Island) are included.

610 Records are based on Klimpel et al. (2009) and Oguz et al. (2015). Depth ranges of the fish species 
611 are taken from Froese \& Pauly, (2016). Abbreviations: D, Digenea; C, Cestoda; N, Nematoda; A,

612 Acanthocephala; Cr, Crustacea; H, Hirudinea.

613 Table S2: Morphometric data on the host species investigated. $\mathrm{n}=$ sample size, $\mathrm{TL}=$ total

614 length, $\mathrm{TW}=$ total weight, $\mathrm{SW}=$ slaughter weight. Arithmetric mean and standard deviation are

615 given. Median, minimum and maximum are given below. $\mathrm{K}=$ condition factor, HSI = 616 hepatosomatic index.

617 Table S3: Molecular results. Nematodes subjected to molecular analyses and identity matching 618 with the NCBI data set (GenBank). ID = Sample code: Species initials_Host-No._Nematode-No., 619 Organism $=$ Species of highest identity in GenBank, \% Identity: Pairwise identity of query and 620 organism.

621 Alignment S4: MUSCLE sequence alignment of the obtained cox2 sequences including 622 species references. Complete alignment that has been used for subsequent phylogenetic analyzes. 623 Sequence IDs according to Table S3 and Fig. 3. Reference sequences were obtained from Genbank 624 (Accession numbers indicated).

625 Raw Data S5: Description of raw data including sampling information, morphological 626 measurements and stomach contents. ID = identification code of the examined fish specimens 627 (C.w: Chaenodraco wilsoni; C.g: Champsocephalus gunnari; N.i: Neopagetopsis ionah; P.m: 628 Pagetopsis macropterus; P.g: Pseudochaenichthys georgianus). Hol = sampling point, SL = 629 standard length, $\mathrm{TL}=$ total length, $\mathrm{TW}=$ total weight, $\mathrm{CW}=$ carcass weight, $\mathrm{GO}=$ gonad weight, $630 \mathrm{LW}=$ liver weight, $\mathrm{SW}=$ stomach weight, $\mathrm{FW}=$ food item weight.

631 Raw Data S6: Raw data of parasitological examination. Given numbers are the amount of 632 recorded parasite specimens. ID = identification code of the examined specimens. Hir: Hirudinea, 633 N. saw: Nototheniobdella sawyeri, N. noto: Notobdella nototheniae, T. cap: Truliobdella capitis, 
634 Ne: Nematoda, C. osc: Contracaecum osculatum (s.l.), C. rad: C. radiatum, C. sp.: Contracaecum 635 sp., P. dec: Pseudoterranova decipiens (s.1.), A. not: Ascarophis nototheniae, Dig: Digenea, N. 636 ant: Neolebouria antarctica, M. geo: Macvicaria georgiana, G. phy: Gonocerca phycidis, E. oat: 637 Elytrophalloides oatesi, Ces: Cestoda, Db: Diphyllobothriidea, Te: Tetraphyllidae, Ac: 638 Acanthocephala, C. bul: Corynosoma bullosum, Cr: Crustacea, E. ant: Eubrachiella antarctica. 639 


\section{Table $\mathbf{1}$ (on next page)}

Trawl and catch data.

Information on date, position ( $\mathrm{S}=$ south, $\mathrm{W}=$ west) and depth $[\mathrm{m}]$ are given for each station. For some trawls data about the duration or position were missing (n.d). The number of individuals caught $[\mathrm{n}]$ is given for each species (C. g. = Champsocephalus gunnari, $C$. w. $=$ Chaenodraco wilsoni, $N . i .=$ Neopagetopsis ionah, $P . m .=$ Pagetopsis macropterus, $P . g .=$ Pseudochaenichthys georgianus). 
1 Table 1: Trawl and catch data. Information on date, position $(\mathrm{S}=$ south, $\mathrm{W}=$ west $)$ and depth [m] are given for each station. For some trawls data about the duration or position were missing (n.d). The number of individuals caught [n] is given for each species (C. g. = Champsocephalus gunnari, C. w. = Chaenodraco wilsoni, $N$. i. = Neopagetopsis ionah, . m. = Pagetopsis macropterus, P. g. = Pseudochaenichthys georgianus).

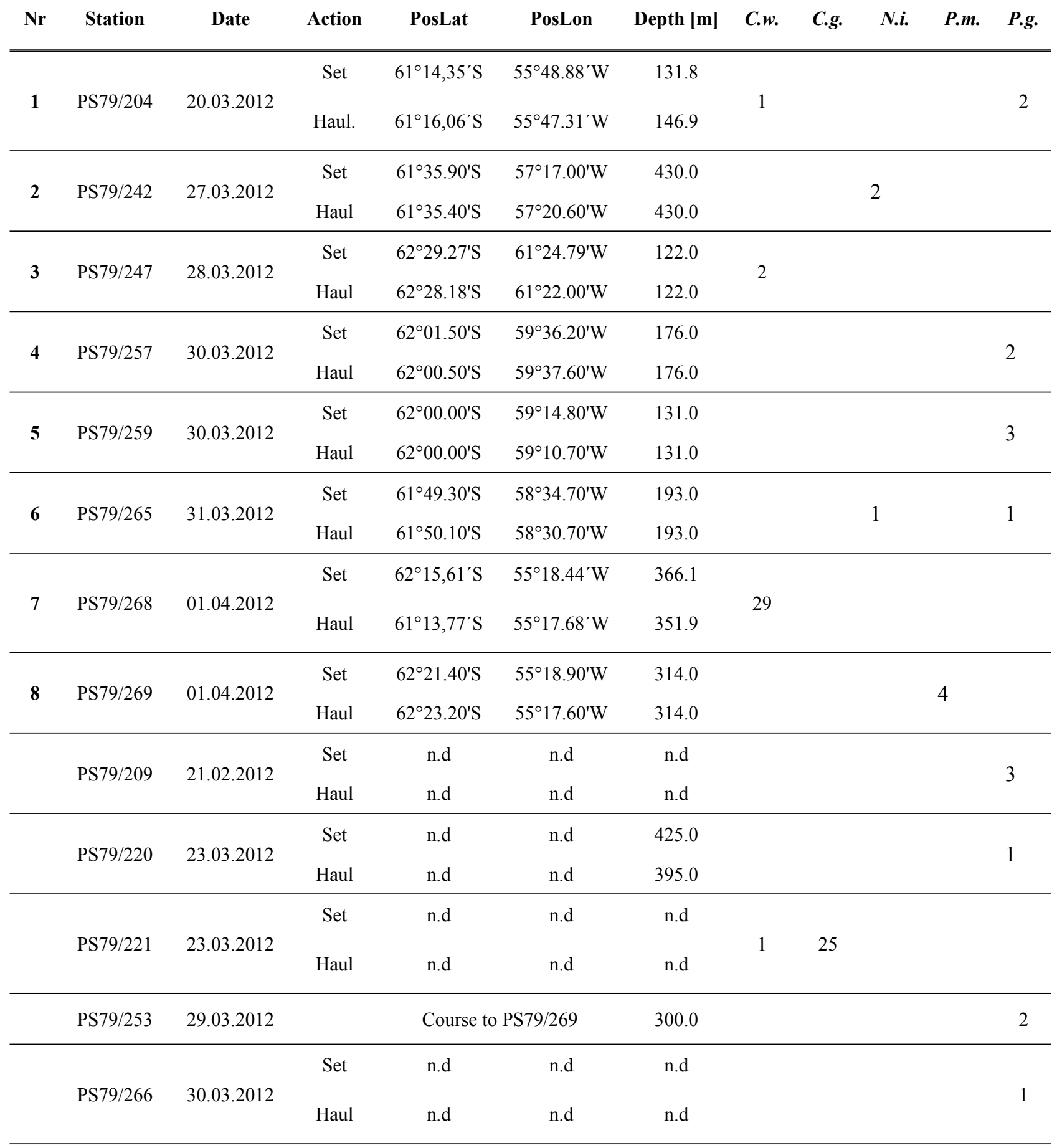




\section{Table 2 (on next page)}

Parasitological data from the examined channichthyid Pseudochaenichthys georgianus.

$\mathrm{A}=$ adult; $\mathrm{Lv}=$ larval; $\mathrm{BC}=$ body cavity, $\mathrm{L}=$ liver, $\mathrm{S}=$ stomach, $\mathrm{I}=$ intestine, $\mathrm{P}=$ pylorus, $\mathrm{FT}$ = fat tissue, $\mathrm{SU}=$ surface, $\mathrm{MC}=$ mouth cavity, $\mathrm{G}=$ gills; $\mathrm{n}=$ total number of parasites, Location = location of the parasite inside the host, $\mathrm{P}[\%]=$ prevalence, $\mathrm{MI}=$ mean intensity, $\mathrm{I}$ = intensity (in parantheses), $\mathrm{MA}=$ mean abundance, $\mathrm{H}^{\prime}=$ diversity index, $\mathrm{J}^{\prime}=$ eveness. Parasites isolated from stomach and intestine, were located in the lumen of these organs. New host records are marked with an asterisk $(*)$. 
1 Table 2: Parasitological data from the examined channichthyid Pseudochaenichthys georgianus. A = adult; $\mathrm{Lv}=$ larval; $\mathrm{BC}$ = body cavity, $\mathrm{L}=$ liver, $\mathrm{S}=$ stomach, $\mathrm{I}=$ intestine, $\mathrm{P}=$ pylorus, $\mathrm{FT}=$ fat tissue, $\mathrm{SU}=$ surface, $\mathrm{MC}=$ mouth cavity, $\mathrm{G}=$ gills; $\mathrm{n}=$ total number of parasites, Location $=$ location of the parasite inside the host, $\mathrm{P}[\%]=$ prevalence, $\mathrm{MI}=$ mean intensity, $\mathrm{I}=$ intensity (in parantheses), $\mathrm{MA}=$ mean abundance, $\mathrm{H}^{\prime}=$ diversity index, $\mathrm{J}^{\prime}=$ eveness. Parasites isolated from stomach and intestine, were located in the lumen of these organs. New host records are marked with an asterisk $(*)$.

\begin{tabular}{|c|c|c|c|c|c|c|c|c|c|}
\hline Species & Parasite & Stage & Location & $\mathbf{N}$ & $\mathbf{P}[\%]$ & MI (I) & MA & $\mathbf{H}^{\prime}$ & $\mathbf{J}^{\prime}$ \\
\hline \multirow{11}{*}{$\begin{array}{l}\text { Pseudochaenichthys } \\
\text { georgianus }\end{array}$} & Digenea & & SP & 7 & 20.0 & 2.3 & 0.5 & & \\
\hline & Elytrophalloides oatesi & A & S & 1 & 13.3 & $2.5(1-4)$ & 0.3 & & \\
\hline & Gonocerca phycidis & A & S & 5 & 6.7 & $1.0(1)$ & 0.1 & & \\
\hline & Neolebouria antarctica & A & $\mathrm{P}$ & 1 & 6.7 & $1.0(1)$ & 0.1 & & \\
\hline & Nematoda & & $\mathrm{BC} / \mathrm{L} / \mathrm{S} / \mathrm{I} / \mathrm{P} / \mathrm{FT}$ & 460 & 93.3 & 32.8 & 30.7 & & \\
\hline & Ascarophis nototheniae* & A & $\mathrm{S}$ & 1 & 6.7 & $1.0(1)$ & 0.1 & & \\
\hline & $\begin{array}{l}\text { Contracaecum osculatum } \\
(\text { s.l. })^{*}\end{array}$ & $\mathrm{Lv}$ & $\mathrm{BC} / \mathrm{L} / \mathrm{S} / \mathrm{I} / \mathrm{P} / \mathrm{FT}$ & 240 & 93.3 & $17.1(2-54)$ & 16.0 & & \\
\hline & Contracaecum radiatum* & Lv & $\mathrm{BC} / \mathrm{L} / \mathrm{S} / \mathrm{I} / \mathrm{P}$ & 171 & 86.7 & $13.2(1-34)$ & 11.4 & & \\
\hline & Contracaecum sp. & Lv & $\mathrm{BC} / \mathrm{L} / \mathrm{S} / \mathrm{P}$ & 13 & 42.9 & $2.2(1-4)$ & 0.9 & & \\
\hline & Nematoda indet & $\mathrm{Lv}$ & $\mathrm{L} / \mathrm{I}$ & 1 & 13.3 & $1.0(1)$ & 0.1 & & \\
\hline & $\begin{array}{l}\text { Pseudoterranova } \\
\text { decipiens (s.l.) }\end{array}$ & $\mathrm{Lv}$ & $\mathrm{BC} / \mathrm{L} / \mathrm{S}$ & 33 & 33.3 & $6.6(2-16)$ & 2.2 & 1.5 & 0.6 \\
\hline \multirow[t]{10}{*}{$(n=15)$} & Cestoda & & $\mathrm{BC} / \mathrm{L} / \mathrm{S} / \mathrm{I} / \mathrm{P} / \mathrm{FT}$ & 1774 & 100 & 118.3 & 118.3 & & \\
\hline & $\begin{array}{l}\text { Diphylloboththriidea } \\
\text { indet }\end{array}$ & $\mathrm{Lv}$ & $\mathrm{BC} / \mathrm{L} / \mathrm{S} / \mathrm{I} / \mathrm{P} / \mathrm{FT}$ & 612 & 80.0 & $51.0(1-170)$ & 40.8 & & \\
\hline & Tetraphyllidae indet & $\mathrm{Lv}$ & $\mathrm{BC} / \mathrm{L} / \mathrm{S} / \mathrm{I} / \mathrm{P} / \mathrm{FT}$ & 1162 & 100 & $77.5(4-238)$ & 77.5 & & \\
\hline & Acanthocephala & & $\mathrm{BC} / \mathrm{S} / \mathrm{P}$ & 5 & 20.0 & 1.7 & 0.3 & & \\
\hline & Corynosoma bullosum* & $\mathrm{Lv}$ & $\mathrm{BC} / \mathrm{S} / \mathrm{P}$ & 5 & 20.0 & $1.7(1-3)$ & 0.3 & & \\
\hline & Hirudinae & & $\mathrm{SU} / \mathrm{MC} / \mathrm{G}$ & 8 & 33.3 & 1.6 & 0.5 & & \\
\hline & $\begin{array}{l}\text { Nototheniobdella } \\
\text { sawyeri* }\end{array}$ & A & $\mathrm{MC} / \mathrm{G}$ & 6 & 26.7 & $1.5(1-3)$ & 0.4 & & \\
\hline & Trulliobdella capitis & A & SU & 2 & 13.3 & $1.0(1)$ & 0.1 & & \\
\hline & Copepoda & & SU & 1 & 6.7 & 1.0 & 0.0 & & \\
\hline & Eubrachiella antarctica* & A & SU & 1 & 6.7 & $1.0(1)$ & 0.1 & & \\
\hline
\end{tabular}




\section{Table 3 (on next page)}

Parasitological data from the examined channichthyids Chaenodraco wilsoni, Chamsocephalus gunnari, Neopagetopsis ionah, and Pagetopsis macropterus.

$\mathrm{A}=$ adult; $\mathrm{Lv}=$ larval; $\mathrm{BC}=$ body cavity, $\mathrm{L}=$ liver, $\mathrm{S}=$ stomach, $\mathrm{I}=$ intestine, $\mathrm{P}=$ pylorus, $\mathrm{FT}$ = fat tissue, $\mathrm{SU}=$ surface, $\mathrm{MC}=$ mouth cavity, $\mathrm{G}=$ gills, $\mathrm{n}=$ total number of parasites, Location = location of the parasite inside the host, $\mathrm{P}[\%]=$ prevalence, $\mathrm{MI}=$ mean intensity, $\mathrm{I}$ = intensity (in parantheses), $\mathrm{MA}=$ mean abundance, $\mathrm{H}^{\prime}=$ diversity index, $\mathrm{J}^{\prime}=$ eveness. Parasites isolated from stomach and intestine were located in the lumen of these organs. New host records are marked with an asterisk $(*)$. 
1 Table 3: Parasitological data from the examined channichthyids Chaenodraco wilsoni, Champsocephalus gunnari, Neopagetopsis ionah, and Pagetopsis macropterus. $\mathrm{A}=$ adult; $\mathrm{Lv}=$ larval; $\mathrm{BC}=$ body cavity, $\mathrm{L}=$ liver, $\mathrm{S}=\mathrm{stomach}, \mathrm{I}=$ intestine, $\mathrm{P}=$ pylorus, $\mathrm{FT}=$ fat tissue, $\mathrm{SU}=$ surface, $\mathrm{MC}=$ mouth cavity, $\mathrm{G}=$ gills, $\mathrm{n}=$ total number of parasites, Location $=$ location of the parasite inside the host, $\mathrm{P}[\%]=$ prevalence, $\mathrm{MI}=$ mean intensity, $\mathrm{I}=$ intensity (in parantheses), $\mathrm{MA}=$ mean abundance, $\mathrm{H}^{\prime}=$ diversity index, $\mathrm{J}^{\prime}=$ eveness. Parasites isolated from stomach and intestine, were located in the lumen of these organs. New host records are marked with an asterisk $(*)$.

\begin{tabular}{|c|c|c|c|c|c|c|c|c|c|}
\hline Species & Parasite & Stage & Location & $\mathbf{n}$ & $\mathbf{P}[\%]$ & MI (I) & MA & $\mathbf{H}^{\prime}$ & $\mathbf{J}^{\prime}$ \\
\hline \multirow{13}{*}{$\begin{array}{l}\text { Chaenodraco wilsoni } \\
(\mathrm{n}=33)\end{array}$} & Digenea & & $\mathbf{S} / \mathbf{I} / \mathbf{P}$ & 3 & 6.1 & 1.5 & 0.1 & \multirow{13}{*}{1.9} & \multirow{13}{*}{0.8} \\
\hline & Neolebouria antarctica & A & $\mathrm{S} / \mathrm{I} / \mathrm{P}$ & 3 & 6.1 & $1.5(1-2)$ & 0.1 & & \\
\hline & Nematoda & & $\mathbf{L} / \mathbf{S} / \mathbf{I} / \mathbf{P}$ & 58 & 48.5 & 3.9 & 1.9 & & \\
\hline & $\begin{array}{l}\text { Contracaecum osculatum } \\
(\text { s.l. })^{*}\end{array}$ & $\mathrm{Lv}$ & $\mathrm{L}$ & 35 & 39.4 & $2.7(1-7)$ & 1.1 & & \\
\hline & Contracaecum radiatum* & $\mathrm{Lv}$ & $\mathrm{L} / \mathrm{S} / \mathrm{I} / \mathrm{P}$ & 17 & 33.3 & $1.5(1-3)$ & 0.5 & & \\
\hline & Contracaecum sp. & $\mathrm{Lv}$ & $\mathrm{L}$ & 6 & 3.0 & $6.0(6)$ & 0.2 & & \\
\hline & Nematoda indet & $\mathrm{Lv}$ & $\mathrm{L} / \mathrm{P}$ & 5 & 12.1 & $1.3(1-2)$ & 0.2 & & \\
\hline & Cestoda & & $\mathbf{L} / \mathbf{F} / \mathbf{T}$ & 10 & 30.3 & 2.5 & 0.3 & & \\
\hline & Diphyllobothriidea indet & $\mathrm{Lv}$ & $\mathrm{L} / \mathrm{FT}$ & 10 & 30.3 & $2.5(1-4)$ & 0.3 & & \\
\hline & Hirudinea & & $\mathrm{S} / \mathbf{M C} / \mathbf{G}$ & 43 & 30.3 & 1.4 & 0.4 & & \\
\hline & Notobdella nototheniae* & A & S & 32 & 15.2 & $6.4(1-20)$ & 1.0 & & \\
\hline & Nototheniobdella sawyeri & A & $\mathrm{MC} / \mathrm{G}$ & 9 & 21.2 & 1.3 & 0.3 & & \\
\hline & Trulliobdella capitis & A & $\mathrm{S}$ & 2 & 6.1 & $1.0(1)$ & 0.1 & & \\
\hline \multirow{9}{*}{$\begin{array}{l}\text { Champsocephalus } \\
\text { gunnari }\end{array}$} & Digenea & & $\mathbf{P}$ & 2 & 8.0 & 1.0 & 0.1 & \multirow{9}{*}{1.6} & \multirow{9}{*}{0.9} \\
\hline & Macvicaria georgiana* & A & $\mathrm{P}$ & 2 & 8.0 & $1.0(1)$ & 0.1 & & \\
\hline & Nematoda & & $\mathrm{BC} / \mathrm{L} / \mathrm{S} / \mathrm{I} / \mathbf{P}$ & 51 & 72.0 & 2.8 & 2.0 & & \\
\hline & $\begin{array}{l}\text { Contracaecum osculatum } \\
\text { (s.l. })^{*}\end{array}$ & $\mathrm{Lv}$ & $\mathrm{L} / \mathrm{P}$ & 14 & 40.0 & $1.4(1-2)$ & 0.6 & & \\
\hline & Contracaecum radiatum* & $\mathrm{Lv}$ & $\mathrm{L} / \mathrm{I} / \mathrm{P}$ & 10 & 28.0 & $1.4(1-3)$ & 0.4 & & \\
\hline & Contracaecum sp. & $\mathrm{Lv}$ & $\mathrm{P}$ & 5 & 16.0 & $1.2(1-2)$ & 0.2 & & \\
\hline & Nematoda indet & $\mathrm{Lv}$ & $\mathrm{BC} / \mathrm{L} / \mathrm{S} / \mathrm{I} / \mathrm{P}$ & 22 & 48.0 & $1.8(1-6)$ & 0.9 & & \\
\hline & Cestoda & & $\mathbf{L} / \mathbf{S} / \mathbf{P} / \mathbf{F T}$ & 9 & 28.0 & 1.3 & 0.4 & & \\
\hline & Diphyllobothriidea indet & $\mathrm{Lv}$ & $\mathrm{L} / \mathrm{S} / \mathrm{P} / \mathrm{FT}$ & 9 & 28.0 & $1.3(1-2)$ & 0.4 & & \\
\hline \multirow{6}{*}{$\begin{array}{l}\text { Neopagetopsis ionah } \\
(\mathrm{n}=3)\end{array}$} & Nematoda & & $\mathbf{L} / \mathbf{S} / \mathbf{P}$ & 9 & 100 & 3.0 & 3.0 & \multirow{6}{*}{1.2} & \multirow{6}{*}{0.5} \\
\hline & $\begin{array}{l}\text { Contracaecum osculatum } \\
(\text { s.l. })^{*}\end{array}$ & $\mathrm{Lv}$ & $\mathrm{L}$ & 6 & 100 & $2.0(1-3)$ & 2.0 & & \\
\hline & Contracaecum radiatum* & $\mathrm{Lv}$ & $\mathrm{P}$ & 2 & 66.7 & $1.0(1)$ & 0.7 & & \\
\hline & Contracaecum sp. & $\mathrm{Lv}$ & $\mathrm{S}$ & 1 & 33.3 & $1.0(1)$ & 0.3 & & \\
\hline & Cestoda & & BC/L/S & 5 & 66.7 & 2.5 & 1.7 & & \\
\hline & Diphyllobothriidea indet & $\mathrm{Lv}$ & $\mathrm{BC} / \mathrm{L} / \mathrm{S}$ & 5 & 66.7 & $2.5(2-3)$ & 1.7 & & \\
\hline \multirow{7}{*}{$\begin{array}{l}\text { Pagetopsis } \\
\text { macropterus }\end{array}$} & Nematoda & & $\begin{array}{c}\mathrm{BC} / \mathrm{L} / \mathrm{S} / \mathrm{I} / \mathbf{F} \\
\mathrm{T}\end{array}$ & 44 & 100 & 11.0 & 11.0 & \multirow{7}{*}{1.0} & \multirow{7}{*}{0.7} \\
\hline & $\begin{array}{l}\text { Contracaecum osculatum } \\
(\text { s.l. })^{*}\end{array}$ & $\mathrm{Lv}$ & $\mathrm{BC} / \mathrm{L} / \mathrm{S} / \mathrm{FT}$ & 34 & 100 & $8.5(3-19)$ & 8.5 & & \\
\hline & Contracaecum radiatum* & $\mathrm{Lv}$ & $\mathrm{L} / \mathrm{S} / \mathrm{I} / \mathrm{FT}$ & 10 & 100 & $2.5(1-6)$ & 2.5 & & \\
\hline & Cestoda & & $\mathrm{BC} / \mathrm{L} / \mathrm{S} / \mathbf{F T}$ & 65 & 100 & 16.3 & 16.3 & & \\
\hline & Diphyllobothriidea indet & $\mathrm{Lv}$ & $\mathrm{BC} / \mathrm{L} / \mathrm{S} / \mathrm{FT}$ & 65 & 100 & $16.3(7-34)$ & 16.3 & & \\
\hline & Hirudinea & & $\mathbf{M C} / \mathbf{G}$ & 4 & 50.0 & 2,0 & 4.0 & & \\
\hline & Nototheniobdella sawyeri & A & $\mathrm{MC} / \mathrm{G}$ & 4 & 50.0 & $2.0(1-3)$ & 4.0 & & \\
\hline
\end{tabular}




\section{Table 4(on next page)}

Food items isolated from the five channichthyid species.

$\mathrm{F}[\%]$ : frequency of occurrence; $N[\%]$ : numerical percentage of prey; W[\%]: weight percentage of prey; IRI: index of relative importance. 
1 Table 4: Food items isolated from the five channichthyid species. F[\%]: frequency of occurrence; N[\%]: numerical percentage 2 of prey; W[\%]: weight percentage of prey; IRI: index of relative importance.

\begin{tabular}{|c|c|c|c|c|c|}
\hline Fish species & Food item & $\mathbf{F}[\%]$ & $\mathbf{N}[\%]$ & $\mathbf{W}[\%]$ & IRI \\
\hline C. wilsoni & Crustacea indet. & 60.9 & 35.3 & 33.3 & 4177.7 \\
\hline \multirow[t]{3}{*}{$(n=33)$} & Euphausiacea & 47.8 & 57.6 & 59.0 & 5573.5 \\
\hline & Euphausia sp. & 30.4 & 39.5 & 32.9 & 2201.0 \\
\hline & Euphausia superba & 17.4 & 26.5 & 29.3 & 970.9 \\
\hline C. gunnari & Crustacea indet. & 33.3 & 10.0 & 10.0 & 666.0 \\
\hline \multirow[t]{4}{*}{$(n=25)$} & Amphipoda & 8.3 & 1.5 & 0.3 & 14.9 \\
\hline & Euphausiacea & 83.3 & 90.5 & 88.6 & 14919.0 \\
\hline & Euphausia sp. & 54.2 & 62.1 & 52.8 & 6227.6 \\
\hline & Euphausia superba & 29.2 & 23.4 & 35.9 & 1731.6 \\
\hline N. ionah & Crustacea indet. & 50.0 & 23.2 & 8.3 & 1575.0 \\
\hline \multirow[t]{2}{*}{$(n=3)$} & Euphausiacea & 50.0 & 76.8 & 91.7 & 8425.0 \\
\hline & Euphausia sp. & 50.0 & 76.8 & 91.7 & 8425.0 \\
\hline P. macropterus & Crustacea indet. & 75.0 & 62.2 & 58.2 & 9030.0 \\
\hline \multirow[t]{2}{*}{$(n=4)$} & Euphausiacea & 25.0 & 37.8 & 41.8 & 1990.0 \\
\hline & Euphausia sp. & 25.0 & 37.8 & 41.8 & 1990.0 \\
\hline P. georgianus & Crustacea indet. & 50.0 & 11.5 & 8.1 & 980.0 \\
\hline \multirow[t]{2}{*}{$(n=15)$} & Euphausiacea & 50.0 & 88.5 & 84.0 & 8625.0 \\
\hline & Euphausia sp. & 50.0 & 88.5 & 84.0 & 8625.0 \\
\hline
\end{tabular}

3 
Figure 1 (on next page)

Sampling locations off the Antarctic Peninsula.

Specific information on coordinates of the stations (1-8) are summarized in Table 1. Map data (c) Esri, DeLorme, GEBCO, NOAA, NGDC. 


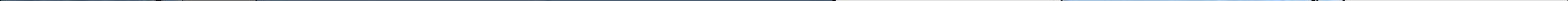




\section{Figure 2 (on next page)}

Relative composition of parasite taxa found in five channichthyid fish species.

Results are based on parasite prevalence. Cestoda and Nematoda were present in all examined fish species. White: Digenea, light grey: Cestoda, medium grey: Acanthocephala, grey dots: Nematoda, dark grey: Hirudinea, black: Crustacea. 


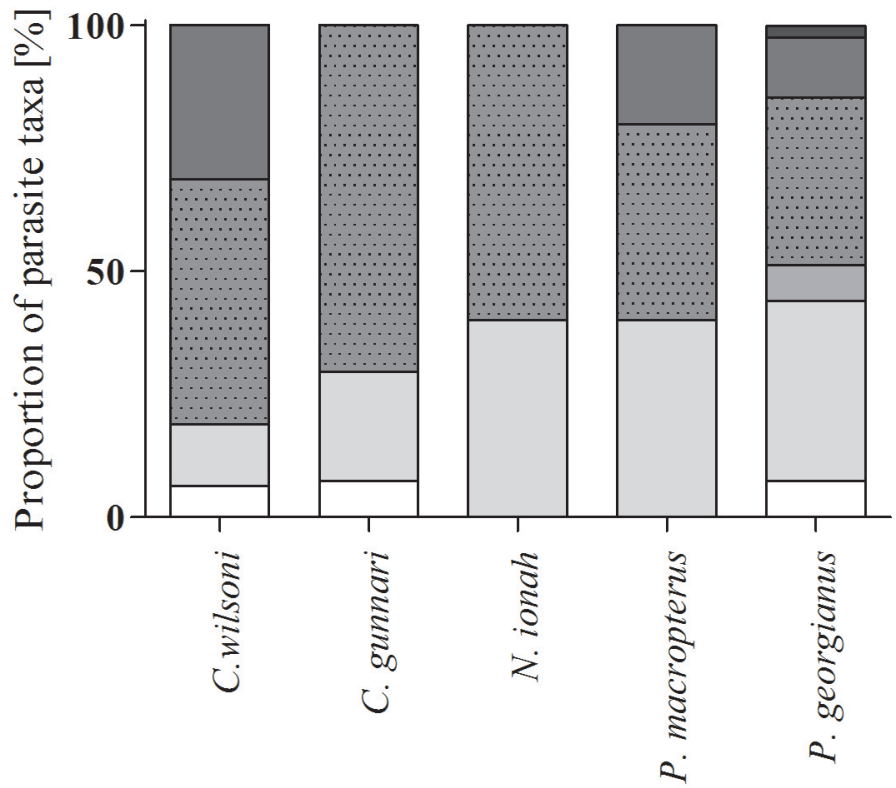


Figure 3 (on next page)

Phylogenetic tree of nematode sequences.

Phylogenetic reconstruction of 117 obtained sequences and 19 anisakid reference species. Branch support values are given for the consensus tree constructed from 9902 original raw trees. For sample abbreviations please see Table $\mathrm{S3}$. The following sample-coding was used: "Species initials_Host-Nr._Nematode-No.". GenBank accession number were given for reference Sequences. 


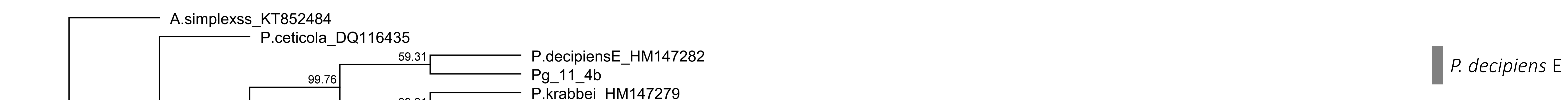

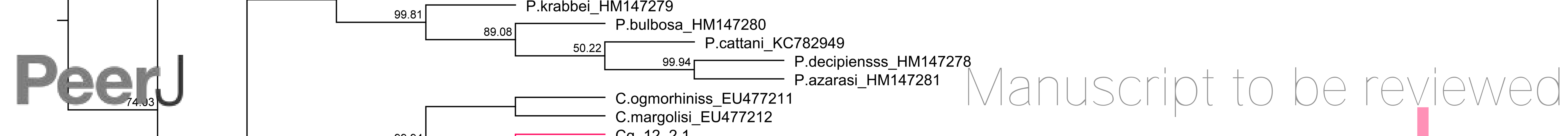

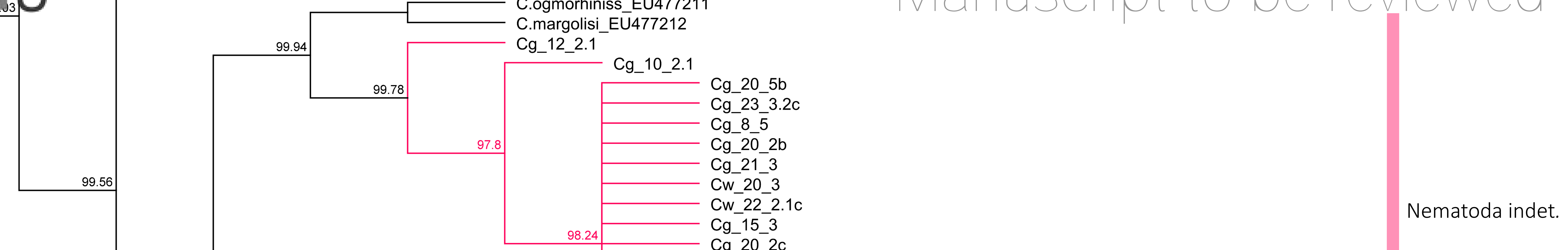

Cw_22_2b

Pg_-12 2.2

- Pm 321

$\mathrm{Cw}_{-} 18.2 .1$

- Cw 1922

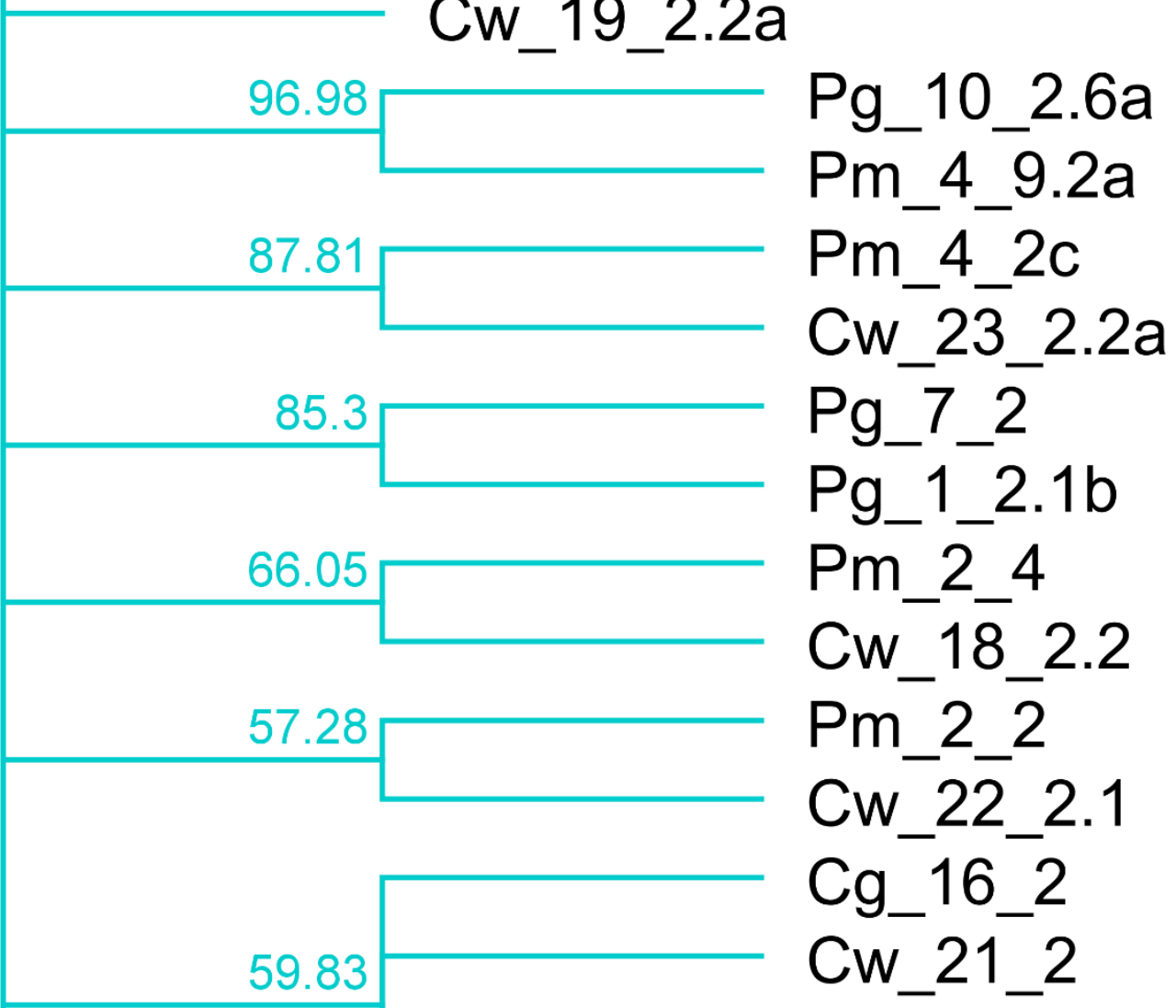

$\mathrm{Pm}_{\mathrm{N}} \mathrm{N}_{-}-2 \mathrm{2h}$

$\mathrm{Pm}_{-}-2 \mathrm{~d}$

Cn- 22 20

Cw_ 14 _2.

CosculatumE_EU47720

$\mathrm{Pg}^{-3}-2.1$

Pm_4 2 2g

Pm_-

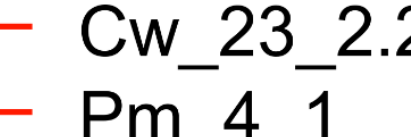

$99.85 \square-\mathrm{Pm}_{-}-1$ 2 $2.1 \mathrm{e}$

$\mathrm{Pm}^{3}-\mathrm{Pm}^{2} \mathrm{P}$
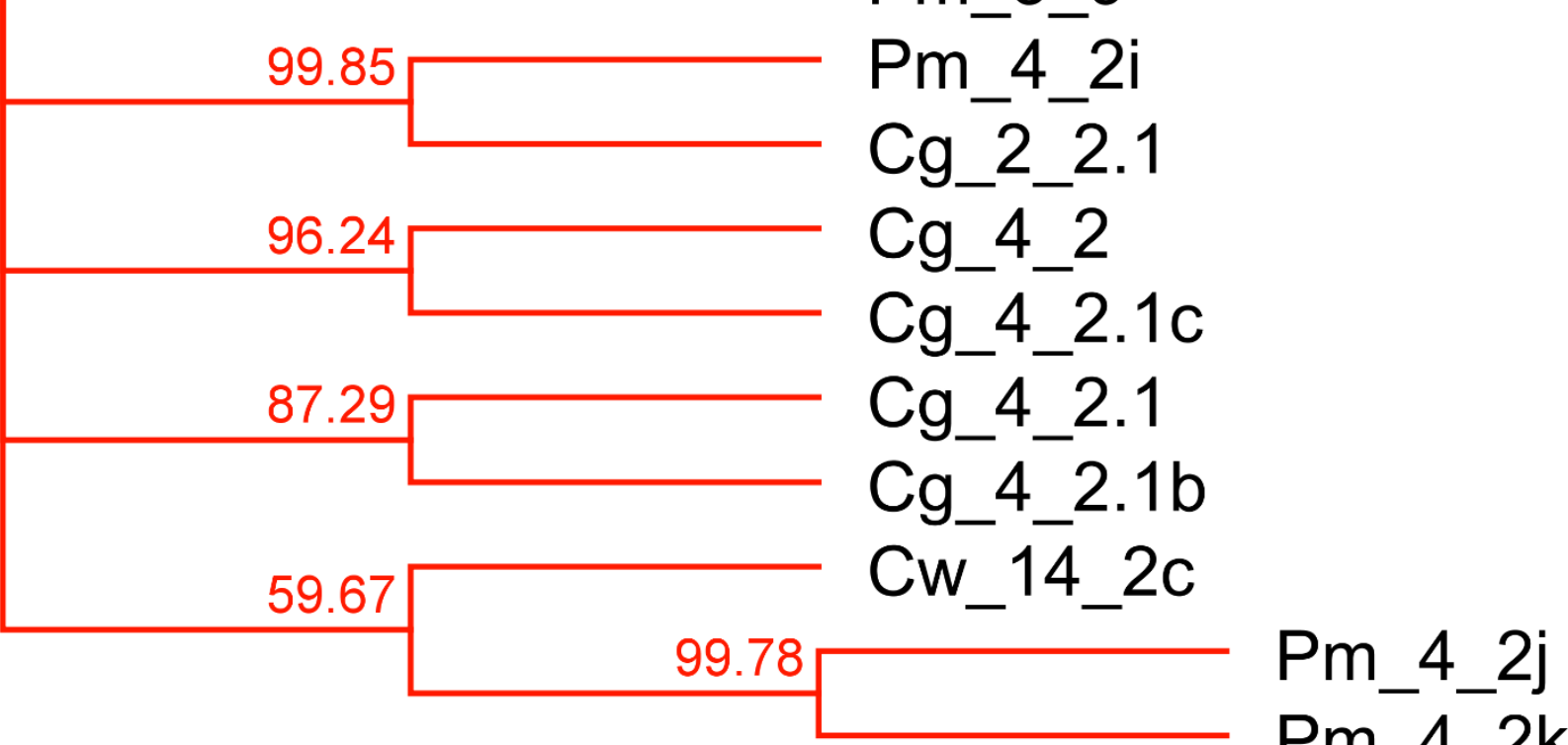